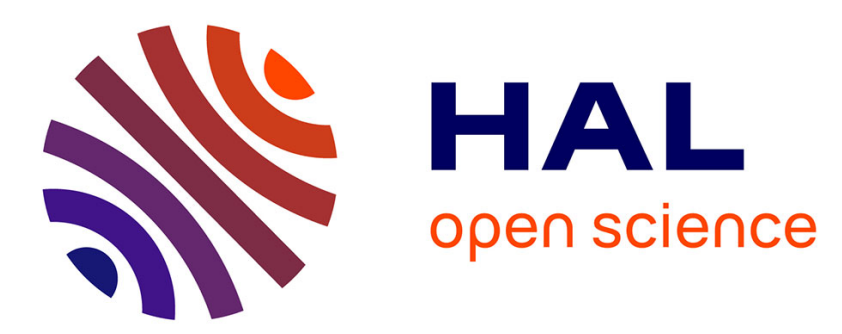

\title{
The publication date, onomatophore and onymotope of Emoia cyanura (Squamata: Scincidae)
}

Annemarie Ohler, Jean Lescure, Jean-Christophe de Massary, Thierry Frétey

\section{To cite this version:}

Annemarie Ohler, Jean Lescure, Jean-Christophe de Massary, Thierry Frétey. The publication date, onomatophore and onymotope of Emoia cyanura (Squamata: Scincidae). Zoosystema, 2021, 43 (25), 10.5252/zoosystema2021v43a25. hal-03445659

\section{HAL Id: hal-03445659 \\ https://hal.sorbonne-universite.fr/hal-03445659}

Submitted on 24 Nov 2021

HAL is a multi-disciplinary open access archive for the deposit and dissemination of scientific research documents, whether they are published or not. The documents may come from teaching and research institutions in France or abroad, or from public or private research centers.
L'archive ouverte pluridisciplinaire HAL, est destinée au dépôt et à la diffusion de documents scientifiques de niveau recherche, publiés ou non, émanant des établissements d'enseignement et de recherche français ou étrangers, des laboratoires publics ou privés. 


\section{zoosystema \\ $2021 \cdot 43 \cdot 25$}

\section{The publication date, onomatophore and onymotope of Emoia cyanura (Squamata: Scincidae)}

Annemarie OHLER, Jean LESCURE, Jean-Christophe de MASSARY \& Thierry FRÉTEY

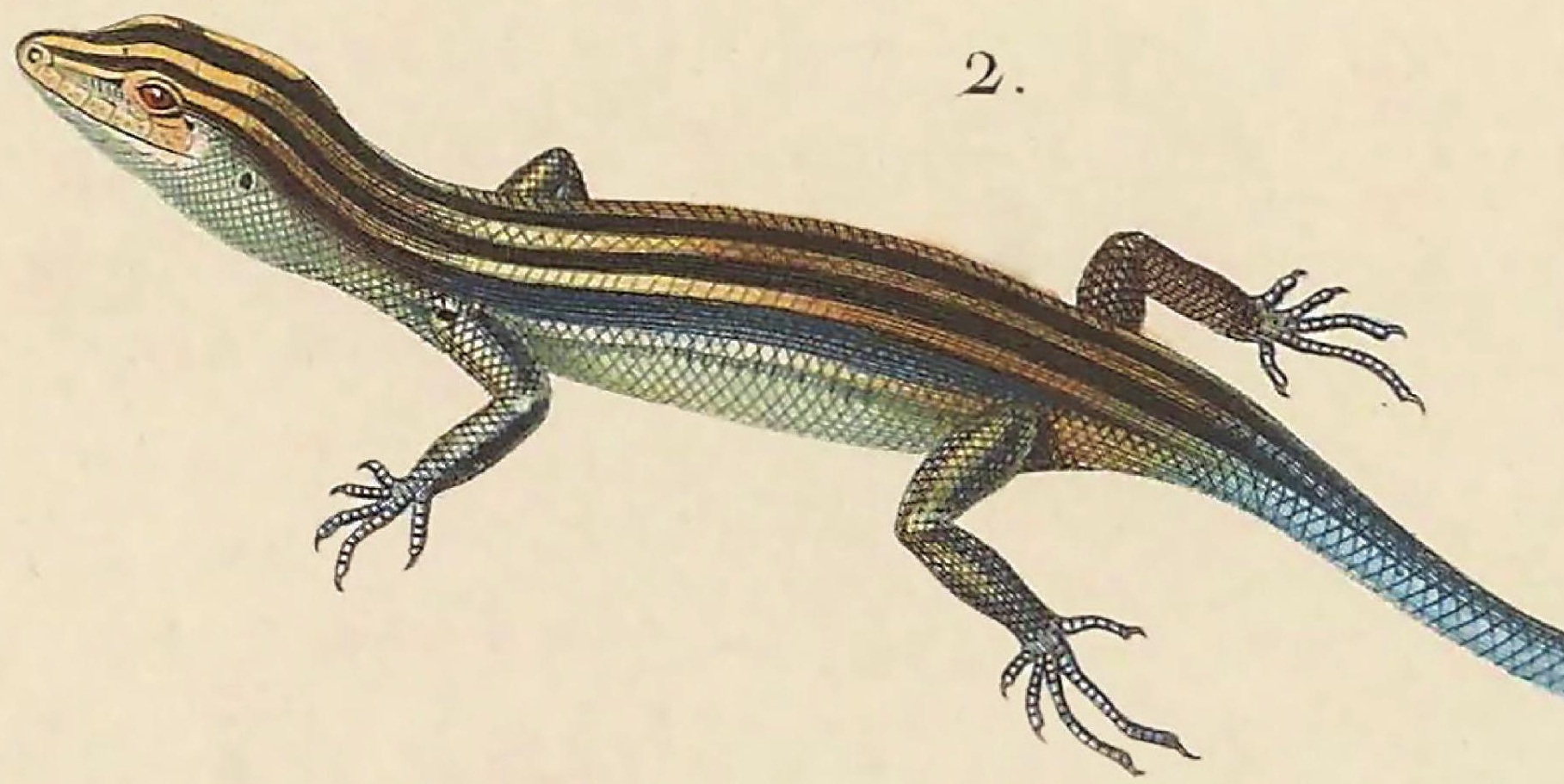


DiRECTEUR de LA PUBLICATION / PUBLICATION DIRECTOR: Bruno David

Président du Muséum national d'Histoire naturelle

RÉDACTRICE EN CHEF / EDITOR-IN-CHIEF : Laure Desutter-Grandcolas

AsSISTANTE DE RÉDACTION / AsSISTANT EDITOR: Anne Mabille (zoosyst@mnhn.fr)

Mise en page / Page Layout: Anne Mabille

COMITÉ SCIENTIFIQUE / SCIENTIFIC BOARD:

Nesrine Akkari (Naturhistorisches Museum, Vienne, Autriche)

Maria Marta Cigliano (Museo de La Plata, La Plata, Argentine)

Serge Gofas (Universidad de Málaga, Málaga, Espagne)

Sylvain Hugel (CNRS, Université de Strasbourg, France)

Marco Isaia (Università degli Studi di Torino, Turin, Italie)

Rafael Marquez (CSIC, Madrid, Espagne)

Jose Christopher E. Mendoza (Lee Kong Chian Natural History Museum, Singapour)

Annemarie Ohler (MNHN, Paris, France)

Jean-Yves Rasplus (INRA, Montferrier-sur-Lez, France)

Wanda M. Weiner (Polish Academy of Sciences, Cracovie, Pologne)

COUVERTURE / COVER:

Emoia cyanura (Lesson, 1830). Holophoront of Scincus cyanurus Lesson, 1830, Gongylus (Eumeces) lessonii Duméril \& Bibron, 1839, Tiliqua lessonii Duméril \& Bibron, 1839 and Tiliqua kienerii Duméril \& Bibron, 1839 as presented on figure 2 of plate 4 in Lesson (1830). Source: https://www.archive.org/download/Voyageautourdum5Dupe/page/n14_w10048

Zoosystema est indexé dans / Zoosystema is indexed in:

- Science Citation Index Expanded (SciSearch $\left.{ }^{\circledR}\right)$

- ISI Alerting Services ${ }^{\circledR}$

- Current Contents ${ }^{\circledR} /$ Agriculture, Biology, and Environmental Sciences ${ }^{\circledR}$

- Scopus ${ }^{\circledR}$

Zoosystema est distribué en version électronique par / Zoosystema is distributed electronically by:

- BioOne ${ }^{\circledR}$ (http://www.bioone.org)

Les articles ainsi que les nouveautés nomenclaturales publiés dans Zoosystema sont référencés par /

Articles and nomenclatural novelties published in Zoosystema are referenced by:

- ZooBank ${ }^{\circledR}$ (http://zoobank.org)

Zoosystema est une revue en flux continu publiée par les Publications scientifiques du Muséum, Paris / Zoosystema is a fast track journal published by the Museum Science Press, Paris

Les Publications scientifiques du Muséum publient aussi / The Museum Science Press also publish:

Adansonia, Geodiversitas, Anthropozoologica, European Journal of Taxonomy, Naturae, Cryptogamie sous-sections Algologie, Bryologie, Mycologie.

Diffusion - Publications scientifiques Muséum national d'Histoire naturelle

CP 41 - 57 rue Cuvier F-75231 Paris cedex 05 (France)

Tél. : 33 (0)1 40794805 / Fax: 33 (0)1 40793840

diff.pub@mnhn.fr / https://sciencepress.mnhn.fr

(C) Publications scientifiques du Muséum national d'Histoire naturelle, Paris, 2021

ISSN (imprimé / print): 1280-9551/ ISSN (électronique / electronic): 1638-9387 


\title{
The publication date, onomatophore and onymotope of Emoia cyanura (Squamata: Scincidae)
}

\author{
Annemarie OHLER \\ Jean LESCURE \\ Institut de Systématique, Évolution, Biodiversité (ISYEB), Muséum national d'Histoire naturelle, \\ CNRS, Sorbonne Université, EPHE, Université des Antilles, \\ case postale 30, 57 rue Cuvier, F-75231 Paris cedex 05 (France) \\ annemarie.ohler@mnhn.fr \\ jean.lescure@mnhn.fr
}

Jean-Christophe de MASSARY

UMS PatriNat (OFB-CNRS-MNHN), Muséum national d'Histoire naturelle, case postale 41, 57 rue Cuvier, F-75231 Paris cedex 05 (France)

jean-christophe.de-massary@mnhn.fr

Thierry FRÉTEY

Association RACINE, 5 allée des Cygnes, 35750 Saint-Maugan (France) fretey.thierry@wanadoo.fr

Submitted on 21 September 2020 | Accepted on 16 Mars 2021 | Published on 5 October 2021 urn:Isid:zoobank.org:pub:BF6E459F-3F5B-4652-9D06-AFB2C983D56F

Ohler A., Lescure J., Massary J.-C. (de) \& Frétey T. 2021. - The publication date, onomatophore and onymotope of Emoia cyanura (Squamata: Scincidae). Zoosystema 43 (25): 619-625. https://doi.org/10.5252/zoosystema2021v43a25. http://zoosystema.com/43/25

\section{ABSTRACT}

The publication date, availability and onymotope of the nomen Scincus cyanurus are assessed. The nomen was validly published by Lesson in 1830 and is based on a holophoront, probably from the island of Tahiti. Elements allowing the identification of the nomina cited in the synonymy of Scincus cyanurus are given. Eumeces lessonii Duméril \& Bibron, 1839 is a replacement name of this nomen (alloneonym) and Emoia pheonura Ineich, 1987 is a subjective synonym (doxisonym) whereas the

KEY WORDS Availability, publication date, synonymy.

MOTS CLÉS

Disponibilité, date de publication, synonymie. nomina Tiliqua lessonii Cocteau and Tiliqua kienerii Cocteau are unavailable as the part of the work of Cocteau proposing these nomina has not been published. The nomen "Scincus celestinus" is a gymnonym (nomen nudum) to be listed in the synonymy of Mocoa caeruleocauda De Vis, 1892 as confirmed by the identity of the specimens from the MNHN collections on which the nomen is based.

\section{RÉSUMÉ}

Date de publication, onomatophore and onymotope of Emoia cyanura (Squamata: Scincidae).

La date de publication, la disponibilité et l'onymotope du nomen Scincus cyanurus sont analysés. Le nomen a été validement publié par Lesson en 1830 et il est basé sur un holophoronte, probablement de l'île de Tahiti. Des éléments permettant la reconnaissance de l'identité des nomina dans la synonymy de Scincus cyanurus basés sur des spécimens du MNHN sont donnés. Ainsi Eumeces lessonii Duméril \& Bibron, 1839 est un nom de remplacement de ce nomen (allonéonyme) et Emoia pheonura Ineich, 1987 est un synonyme subjectif (doxisonyme). En revanche, les nomina Tiliqua lessonii Cocteau et Tiliqua kienerii Cocteau ne sont pas disponibles car cette livraison du travail de Cocteau n'a pas été publiée. Le nomen "Scincus celestinus" est un gymnonyme (nomen nudum) qu'il faut inclure dans la synonymie de Mocoa caeruleocauda De Vis, 1892, confirmé par l'identité des spécimens de la collection du MNHN sur lesquels le nomen est basé. 


\section{INTRODUCTION}

René Primevère Lesson described a series of reptile and amphibian taxa as a result of his participation in the Voyage autour $d u$ monde exécuté par ordre du roi sur la Corvette de sa Majesté La Coquille... Among these the nomen "Scincus cyanurus" refers to a skink widely distributed in the islands of the Pacific now considered valid as Emoia cyanura in the family Scincidae Oppel, 1811. This nomen has been mentioned in three different publications authored by Lesson. The accepted publication date of these works has changed due to new information detailing the printing and distribution of the parts of the Voyage and the parts of the plates of the Atlas (Brygoo 1985; Ineich \& Zug 1991; Cretella 2010; Lescure 2015). The first appearance of the nomen "Scincus cyanurus" was by Lesson in volume 13 of the Annales des Sciences naturelles, in 1828. This work was republished, almost identically in the Zoologie chapter of the Voyage. Finally, the nomen Scincus cyanurus is also associated with figure 2 on plate 4 in the Atlas. Traditionnally dated as 1826 , as the precise publication date of the wrapper was not always taken into account, this figure with a Latin scientific name was considered the original description by several authors (Brygoo 1985; Brown 1991; Ineich \& Zug 1991; Ineich et al. 2009). Guibé (1954) dated both the Atlas and the Zoology volume as 1830 and cited them without distinction.

A new reading of the aspects of the text that assures the status of the nomen "Scincus cyanurus" in Lesson (1828) and new information on the publication dates of the Zoologie volume of the Voyage and the plates of the Atlas (Cretella 2010; Lescure 2015) permit us to reconsider the nomenclatural act and date, and the name-bearing specimens that make the nomen available according the Code (International Code of zoological Nomenclature, Anonymous 1999). The taxonomy used here is based on recent revisions (Brown 1991; Klein et al. 2016).

\section{ABBREVIATIONS}

MNHN Muséum national d'Histoire naturelle, Paris.

NMW Naturhistorisches Museum Wien.

ZMB Museum für Naturkunde Berlin.

\section{NOMENCLATURE}

\section{SCINCUS CYANURUS IN LESSON (1828)}

\section{Is the nomen Scincus cyanurus Lesson, 1828 available?}

When describing the Voyage and its main stops and observations, Lesson (1828: 388) used the nomen Scincus cyanurus first when listing the fauna of Buru [Bourou] Island and gives the following indications: 1) "le petit Scinque à raies dorées et queue bleue" [the small Skink with golden stripes and blue tail]; 2) footnote 1 which refers to "Seba, tom. II, pl. o [sic!], fig. 5"; 3) a Latin nomen "Scincus cyanurus"; and 4) indicates "cette espèce diffère du Scincus vittatus figuré dans Seba sous le nom de "Lacerta Amboinensis teniolis fimbriata" (t. 2, pl. 9, fig. 5 et 6)" [this species is distinct from Scincus vittatus figured in Seba under the name "Lacerta Amboinensis teniolis fimbriata" (t. 2, pl. 9, fig. 5 et 6)].
Lesson (1828) gave a Latin name in 3) and various elements $(1,2,4)$ that could represent indications in the sense of the Code. Lescure (2015) considered that the character states given in 1) satisfy Article 12.2 of the Code (Anonymous 1999) and make the nomen available in that work. But these characters cannot be considered in isolation as Lesson refers them to the footnote giving a citation of Seba. This citation is not clear as there is no plate o or 0 in Seba (1735) (see also Brygoo 1985). Only two plates in Seba's work show lizards as figure 5: plate 4, and plate 9. In plate 4, figure 5 represents a European species, very probably in our opinion the Sand Lizard, Lacerta agilis Linnaeus, 1758. In plate 9, figure 5 is the dorsal view of "Lacerta Amboiensis teniolis fimbriata". In Lesson (1830b), the text of Lesson (1828) is given almost identically but the footnote is indicated as "Seba, tom. II, pl. 9, fig. 5", which confirms our conclusion that "plate o" is a typographic error for plate 9. The same figure of the lizard is mentioned in 4) as being different from the Scincus cyanurus without specifiying the differences. Thus, there are no character states indicated allowing diagnosis of the taxon to which the nomen "Scincus cyanurus" is atttributed. The indication 1) "le petit Scinque à raies dorées et queue bleue" refers to what we might call two 'taxa', the skink from Amboine Island and the blue-tailed skink but is not meant to distinguish the two. Hence, we do not consider Scincus cyanurus as published by Lesson (1828, $1830 \mathrm{~b})$ to be an available name.

What is the onymotope of "Scincus cyanurus" (Lesson, 1828)? Although we conclude that the nomen Scincus cyanurus (Lesson, 1828) is not available, we will now allocate the nomen to a population of skinks in order to be able to cite the gymnonym (nomen nudum) in the correct synonymy list (Dubois \& Raffaëlli 2009: 28). For this we need to know the origin of the specimen or the specimens allocated by Lesson (1828) to the taxon to which he attributed the nomen.

Lesson mentions the taxon in this publication under various names from various places (Table 1). Although he gives a Latin name and descriptive elements when speaking of the skink from Buru Island, he considers that this skink is present in most of the islands from the Society Islands to Java. And in fact, he first observed the species from Tahiti when the Coquille arrived on 3 May 1823 on this island, and after visiting a large number of various islands, on 23 September 1823 on Buru Island. The narrative of Lesson $(1828,1830 a, 1831)$ describes the travel starting from the end. In conclusion, the symprotonymotope (localities as given in the original work) are the islands mentioned in Table 1. It is important to note, that among these localities, Emoia cyanura as understood in works published in the last decades is present in Polynesia, Caroline Islands and Marshall Islands (Brown 1991; Klein et al. 2016; Buden et al. 2020). All other places in Table 1 harbour other blue-tailed species of Emoia, E. caeuleocauda and E. impar.

What is the publication date of Scincus cyanurus?

The nomen Scincus cyanurus is mentioned three times by Lesson. The publication of the Latin name in Lesson (1828) 
TABLE 1. - List of localities (symprotonymotopes) where Lesson (1828) mentions having observed the blue-tailed skink, named "Scincus cyanurus" nomen nudum. Lesson either cited occurance of skinks from proper observations or from literature (skinks from Hawaii mentioned by Quoy \& Gaimard [1824] and skinks from Ratak by Chamisso [1821]). Note, that among these places, Emoia cyanura has been recently cited from Tahiti (Klein et al. 2016), Bora Bora (Glen Shea, personal communication), Kosrae (Buden \& Taboroši 2016) and Marshall Islands (Buden et al. 2020).

\begin{tabular}{|c|c|c|c|c|}
\hline Name of lizard & Locality in Lesson 1828 & pages & Locality name & Island group \\
\hline Scinque à cinq raies, ayant la queue azurée & $\begin{array}{l}\text { Taïti } \\
\text { Borabora } \\
\text { Moluques } \\
\text { Java } \\
\text { Oualan } \\
\text { Nouvelle-Irlande } \\
\text { Waigiou } \\
\text { Amboine }\end{array}$ & $\begin{array}{l}376-377 \\
376-377 \\
376-377 \\
376-377 \\
376-377 \\
376-377 \\
376-377 \\
376-377\end{array}$ & $\begin{array}{l}\text { Tahiti } \\
\text { Bora Bora } \\
\text { Maluku } \\
\text { Kosrae } \\
\text { Lantangai } \\
\text { Waigeo } \\
\text { Ambon }\end{array}$ & $\begin{array}{l}\text { Society Islands } \\
\text { Society Islands } \\
\text { Maluku Islands } \\
\text { Indonesia } \\
\text { Caroline Islands } \\
\text { Bismarck Archipelago } \\
\text { Raja Ampat Islands } \\
\text { Maluku Islands }\end{array}$ \\
\hline Scinque queue-bleue & Port Praslin, New Ireland & 380 & Lantangai & Bismarck Archipelago \\
\hline Le petit scinque queue-bleue & Dorery & 385 & Manokwari & West Papua \\
\hline Le petit scinque à raies dorées et queue bleu & Bourou & $387-388$ & Buru & Maluku Islands \\
\hline Scinque à queue d'azur & Amboine & 389 & Ambon & Maluku Islands \\
\hline Petit Scinque à raies dorées et à queue azuré & $\begin{array}{l}\text { Îles Sandwich } \\
\text { Îles Radack }\end{array}$ & $\begin{array}{l}392 \\
392\end{array}$ & $\begin{array}{l}\text { Hawaii } \\
\text { Ratak }\end{array}$ & $\begin{array}{l}\text { Hawaii, USA } \\
\text { Marshall Islands }\end{array}$ \\
\hline
\end{tabular}

is not accompanied by a diagnosis as we have seen, thus, the nomen is not available from this publication. As a Latin scientific name is clearly linked to a figure of a plate in the Atlas (Lesson 1830a) and as a detailed description is given in the Zoology part of the Voyage (Lesson 1831), the nomen could be available from either publication. There were ambiguities concerning the dates of publication of some parts of these works in two recent papers (Cretella 2010; Lescure 2015), which led us to search again for the dates indicated in the Bibliographie de la France volumes and other sources giving dates of recept of published books and their parts. The summary of our observations is given in Table 2. The publication date of plate 4 representing Scincus cyanurus in figure 2, has been indicated to be as early as 3 April 1830 by Sherborn \& Woodward (1901). The part (livraison) containing page 49 of volume 2 (1) of the Zoology findings of the Voyage (the written description of Scincus cyanurus) was only published on 13 October 1831 (Guérin-Méneville 1838). Thus, the nomen Scincus cyanurus has been made available according to the Code (Article 12.2.7) in 1830 and should be cited as Scincus cyanurus Lesson, 1830.

Several authors have considered the nomen available from the publication of the plate but considered that the Atlas was published in 1826, which is the date of its first part, not including plate 4: Brygoo (1985), Ineich (1987, 2011), Brown (1991), Ineich \& Zug (1991), Ineich et al. (2009); but Cretella (2010) and Lescure (2015) based on previously published evidence, have shown that the publication date of plate 4, that made the nomen available, was 1830 .

The discrepancies between Cretella (2010) and Lescure (2015) come from the fact that two Voyages were published almost simultaneously in Paris at that period: the Voyage autour du Monde of the ships L'Uranie et La Physicienne and the Voyage autour du Monde of the ship La Coquille. The 17th part of the history volume of the Voyage autour du Monde [de L'Uranie et de La Physicienne] of Freycinet is indicated in the Bibliographie de la France, volume 19 at the same time as the $18^{\text {th }}$ part of the Zoology volume of the Voyage autour $d u$ monde [de La Coquille] of Duperrey. The error might arise from the fact that the names of the ships are not indicated, only the authors Freycinet/Duperrey for the publications. It should also be mentioned that nowhere is the publication date of $18^{\text {th }}$ part of the Zoology volume of the Voyage autour $d u$ monde [de La Coquille] of Duperrey given in the Bibliographie de la France volumes (see details in Table 2).

\section{THE ONOMATOPHORE AND ONYMOTOPE} OF SCINCUS CYANURUS LESSON, 1830

As the nomen is based on a figure (Lesson 1830a, plate 4, figure 2; Fig. 1) the onomatophore is the specimen figured (Article 74.4), thus a holophoront (holotype) by monophory. Brown (1991: 66) confirms that it represents the taxon to which the nomen Emoia cyanura has been attributed for almost two centuries now. A holophoront precludes any other designation of onomatophores. The MNHN Reptiles \& Amphibiens Collection holds a series of seven specimens collected during the Voyage of the Coquille and only three among them were indeed identified as Emoia cyanura (Brown 1991). As the specimen figured on plate 4 in Lesson (1830a) cannot be identified among the three specimens of the collections of the MNHN (Brown 1991: 66; Ineich \& Zug 1991: 1134) and as obviously some among the numerous specimens mentioned (Lesson 1831) many have been lost (or donated to other collections), the holophoront figured should be considered lost and a neotype designated. Given the difficulty to allocate nomina of blue-tailed Emoia to taxa and as the figure is inadequate to allow the unambiguous recognition of E. cyanura because the illustration does not show the relevant diagnostic features, this neotype designation is necessary to stabilize taxonomy. Such a specimen should be carefully chosen and studied with traditional and modern methods of taxonomy, in particular genetics, in order to keep taxonomic usage of the nomen Scincus cyanurus. 
TABLE 2. - Dates of publication for the different parts of the Voyage of the ship La Coquille and particularly concerning herpetological subjects. Comments: Format in quarto is a full sheet printed with 8 text pages. The details of the parts (livraison) of the plates are given in the Bulletin des Sciences naturelles et de Géologie and in Cretella (2010). The Bibliographie de la France twice cites the publication of a 16th part, the second stands for the 17th part, as it is followed by part 18. Numbers in bold indicate volumes of journals and books. Abbreviation: Bull. Sci. nat. Geol., Bulletin des sciences naturelles et de géologie.

\begin{tabular}{|c|c|c|c|c|c|c|c|c|c|c|}
\hline Part & Content & $\begin{array}{l}\text { Herptological } \\
\text { content }\end{array}$ & $\begin{array}{l}\text { Bull. Sci. nat. } \\
\text { Geol. }\end{array}$ & $\begin{array}{r}\text { Bibliographie } \\
\text { de la France }\end{array}$ & $\begin{array}{l}\text { Guérin- } \\
\text { Méneville } \\
\text { 1838: } 271\end{array}$ & $\begin{array}{l}\text { Sherborn \& } \\
\text { Woodward } \\
1901\end{array}$ & $\begin{array}{l}\text { Cowan } \\
1970\end{array}$ & $\begin{array}{l}\text { Cretella } \\
2010\end{array}$ & $\begin{array}{l}\text { Lescure } \\
2015\end{array}$ & $\begin{array}{l}\text { Date } \\
\text { retained }\end{array}$ \\
\hline 11 & $\begin{array}{l}6 \text { sheets of text } \\
\text { in- } 4^{\circ} \\
6 \text { plates }\end{array}$ & $\begin{array}{l}\text { Reptiles } \\
\text { pl. 3, 6, } 7\end{array}$ & $17: 267$ & $\begin{array}{l}18 \text { (22): } \\
379-380 \\
30 . V .1829\end{array}$ & - & 30.V.1829 & - & 30.V.1829 & 30.V.1829 & 30.V.1829 \\
\hline 12 & $\begin{array}{l}7 \text { sheets of text } \\
\text { in }-4^{\circ} \\
\text { frontispiece, } \\
5 \text { sheets }\end{array}$ & $\begin{array}{l}\text { Reptiles } \\
\text { pl. } 1,5\end{array}$ & 19: $329-330$ & $\begin{array}{c}18 \text { (27): } 469 \\
4 . \text { VII.1829 }\end{array}$ & - & 4.VII.1929 & - & 4.VII.1829 & 4.VII.1829 & 4.VII.1929 \\
\hline 15 & $\begin{array}{l}6 \text { sheets of texte } \\
\text { in- } 4^{\circ} \\
6 \text { plates }\end{array}$ & $\begin{array}{l}\text { Reptiles } \\
\text { pl. } 2,4\end{array}$ & $21: 309-311$ & $\begin{array}{c}19 \text { (14): } 221 \\
\text { 3.IV.1830 }\end{array}$ & - & 3.IV.1830 & - & 3.IV.1830 & 3.IV.1830 & 3.IV.1830 \\
\hline 17 & $\begin{array}{l}3 \text { sheets of text } \\
\text { in- } 4^{\circ} \\
6 \text { plates }\end{array}$ & $2(1): 1-24$ & 21: 309-311 & $\begin{array}{l}19 \text { (24): } 388 \\
\text { [mentioned } \\
\text { as 16th part] } \\
\text { 12.Vl.1830 }\end{array}$ & 26.V.1830 & 12.VI.1830 & 26.V.1830 & 26.V.1830 & 12.VI.1830 & 26.V.1830 \\
\hline 25 & $\begin{array}{l}27 \text { sheets of text } \\
\text { in- } 4^{\circ} \\
6 \text { plates }\end{array}$ & $2(1): 25-65$ & - & $\begin{array}{l}20(46): 642- \\
643 \\
12 . X I .1831\end{array}$ & 13.X.1831 & 12.XI.1831 & 13.X.1831 & 13.X.1831 & $\begin{array}{l}\text { 24.VII.1830 } \\
\text { [in error] }\end{array}$ & 13.X.1831 \\
\hline 28 & $\begin{array}{l}60 \text { sheets of text } \\
\text { in }-4^{\circ}\end{array}$ & $\begin{array}{l}2 \text { (2) Appendix: } \\
\text { 137-147 }\end{array}$ & - & - & $\begin{array}{c}\text { [foreword: xii } \\
\text { 15.XI.1838] }\end{array}$ & - & 31.XII.1838 & 31.XII.1838 & 31.XII.1838 & 31.XII.1838 \\
\hline
\end{tabular}

The specimen figured most probably comes from Tahiti as the Coquille made a long stop on this island from 3 to 22 May 1823. This allowed extensive exploration of the island. From the headquarters at Pointe de Vénus at the north of the island, Lesson and Jules Louis Lejeune, an artist participating in the Voyage, made an exploration along the Matavai River to the centre of the island (Lesson 1839: 275). Lesson (1839: 283) also mentioned having been to the "pointe de Taoni" for wood cutting. As it was on Tahiti that he first discovered this colorful species, it seems quite evident that he or Jules Louis Lejeune made sketches of a specimen of E. cyanura. Artistic drawings of specimens was part of the work of the naturalists and the artists who participated in the Voyages (Lescure 2015). The published drawing was prepared later in Paris by Antoine Germain Bévalet according to signature of the plate, most probably on a coloured drawing made in the field while Jules Louis Lejeune was preparing the plates of the history part of the Voyages. The time spent on Tahiti and the details provided by Lesson (1839) on this stay are in favour for considering this place as the origin of the figured specimen. Brown (1991) also argued for Tahiti as onymotope.

There might be some doubts about the existence of specimens collected in the first part of the Voyage as Garnot took at least part of them from Sidney to Paris and lost most during a shipwreck at the Cape of Good Hope (Garnot 1825). Nevertheless this did not concern all the specimens. In the "Annexe " published in the part 2 of volume 2 of the Zoology part, Lesson (1838b) reported numerous specimens donated to the MNHN from localities between Brazil and Sidney and, although some may have been donated or lost meanwhile, others are still in the MNHN collections (Lescure 2015). The
Emoia specimens have been catalogised with "Taiti” as origin and cited as such by Duméril \& Bibron (1835).

If we consider that this indication -Tahiti being the onymotope - is too poorly justified, we have to consider that the region including all the places from which Lesson $(1828,1831)$ observed the species he called Scincus cyanurus, "Scinque à cinq raies ayant la queue azurée", "Scinque à queue d'azur", "Scinque queue-bleue", "Le petit scinque queue-bleue" or "Petit Scinque à raies dorées et à queue azurée" (Table 1) form the protonymotope (original type-locality) (Frétey et al. 2018). Then Tahiti would be the best choice for a neophoront (neotype) designation for nomenclatural stability as this population is indeed part of the genetically defined "widespread” E. cyanura of Klein et al. (2016).

\section{Did Brygoo (1985) make a lectotype designation?}

Brygoo (1985) presented each nomen listed in his type catalog with the reference to its original publication and by its onomatophores with information of onymotopes and collectors. Then a historical presentation and discussion of nomenclatural and taxonomic aspects was given.

For Scincus cyanurus, Brygoo cited two sources: Lesson "1826", the plate published in the Atlas and Lesson " 1830 " the second volume of presentation of the zoological results where the reptiles are presented. We now know that the publication dates of the plate where Scincus cyanurus was published is 1830 and that volume 2 was published only in 1831. Brygoo did not consider Lesson (1828) as a possible original publication for this nomen.

In the discussion of the nomenclature of the nomen Scincus cyanurus, Brygoo (1985) cited an unpublished annotation of Brown on an index card in the Reptiles \& Amphibiens collections identifying one of the specimens MNHN 0.7069A as 


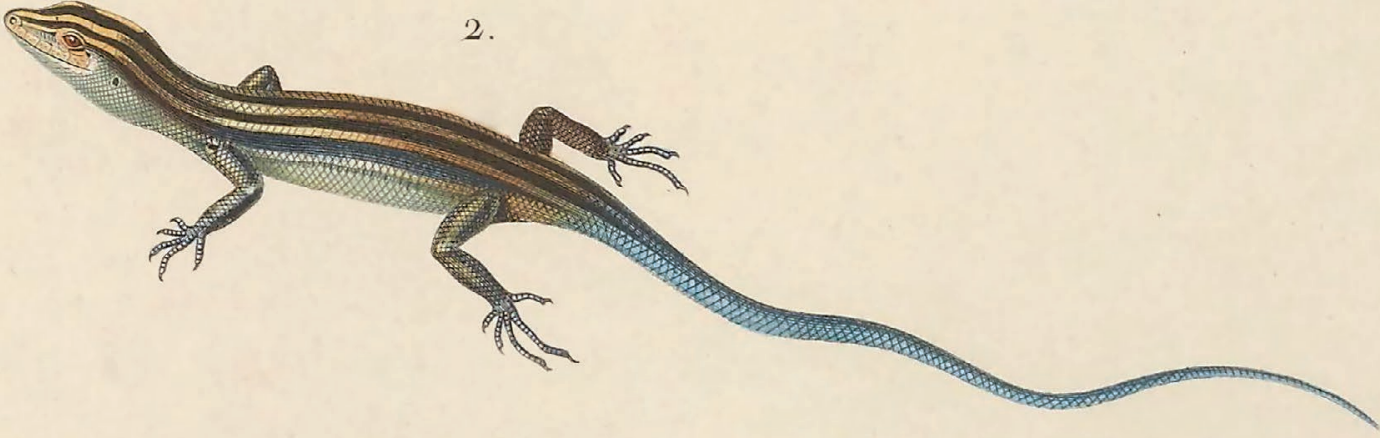

FIG. 1. - Emoia cyanura (Lesson, 1830). Holophoront of Scincus cyanurus Lesson, 1830, Gongylus (Eumeces) lessonii Duméril \& Bibron, 1839, Tiliqua lessonii Duméril \& Bibron, 1839 and Tiliqua kienerii Duméril \& Bibron, 1839 as presented on figure 2 of plate 4 in Lesson (1830). Source: https://www.archive.org/download/Voyageautourdum5Dupe/page/n14_w10048

"lectotype". Brown (1991) and Ineich \& Zug (1991) consider that Brygoo citing the notes of Brown on the index card made a lectotype designation. But Brygoo (1985) expressly stated "sur fiches" [on index cards] thus indicating an unpublished fact. Brygoo (1985) does list "syntypes" for the nomen, thus he did not consider Brown's nomenclatural act as valid. In conclusion, Brygoo did not formally designate a lectophoront (lectotype) for Scincus cyanurus under the provisions of $\mathrm{Ar}$ ticle 74.5 of the Code.

Brown (1991) and Ineich \& Zug (1991), however, considered this to constitute a valid designation. These researchers also agreed that the species nomen was made available by the published figure, thus on a single specimen, and that there is no specimen currently stored in the MNHN collection that could be the specimen figured on plate 4, figure 2 of Lesson (1830a; Fig. 1). As there can be no lectotype designated from a single holophoront, the published designations would be null anyhow.

THE STATUS OF THE NOMINA EUMECES LESSONII, SCINCUS CELESTINUS, TILIQUA LESSONII, TILIQUA KIENERII AND EMOIA PHEONURA

Duméril \& Bibron (1839) mention several other nomina in their synonymy list of Eumeces lessonii (valid nomen Emoia cyanura). We discuss only those that might be based on specimens in the MNHN collection and added the nomenclature of Emoia pheonura Ineich, 1987. The taxonomy adopted is that employed by Brown (1991).

Gongylus (Eumeces) lessonii Duméril \& Bibron, 1839: 654. Status. Alloneonym (replacement name), for Scincus cyanurus Lesson, 1830.
Onomatophore. Same as for the replaced nomen. Specimen represented in figure 2 of plate 4 in Lesson (1830a; Fig. 1).

Onymotope. Same as for the replaced nomen. Islands of Pacific Ocean cited in Lesson (1828, 1831; Table 1).

\section{COMMENT}

Duméril \& Bibron (1839: 655) clearly stated that they created a different name for the taxon as the name of Lesson is not correct in regard to the character he indicated: the coloration of the tail is variable within the species and there are other species that share that character. So Eumeces lessonii is not a poieonym (new name) but a neonym (remplacement name).

"Scincus celestinus"- Duméril \& Bibron 1839: 654.

Status. Gymnonym, unavailable name. Identified as Emoia caeruleocauda (Brown 1991: 77), this nomen should figure in the synonymy list of Mocoa caeruleocauda De Vis, 1892, valid as Emoia caeruleocauda (De Vis, 1892).

Reference specimens. MNHN-RA-0.2917, 2012.507-508 (formerly 2917A, 2917B).

\section{Geographical origin. Ambon Island.}

\section{COMMENT}

Duméril \& Bibron (1839) mentioned the unpublished name Scincus celestinus. Later Duméril \& Duméril (1851: 157) indicated that there are three specimens donated from Museum of Leiden with the name Scincus celestinus in the MNHN collections. These specimens are still in the collections and are in a rather good state of preservation. 
Tiliqua lessonii Cocteau - Duméril \& Bibron 1839: 654.

Status. Alloneonym (replacement name), for Scincus cyanurus Lesson, 1830.

Onomatophore. Same as for the replaced nomen. Specimen represented in figure 2 of plate 4 in Lesson (1830a; Fig. 1).

Onymotope. Same as for the replaced nomen. Specimen represented in figure 2 of plate 4 in Lesson (1830a).

\section{REMARK}

Duméril \& Bibron (1839: 654), Brygoo (1985) and Ineich \& Zug (1991) cite Cocteau (1836), Etudes sur les Scincoïdes as source for this name. We checked four exemplars of the Études sur les Scincoïdes of Cocteau where species of skinks have been described in detail. In fact, only the first part of the book, which was intended to have about 20-25 parts, was published before the death of the author (Anonymous 1838a, b). There is mention of the printing of a second part (Anonymous 1838b: 257) and we found a copy including the title page of the part mentionning Ire Tribu. Scincoides saurophthalmes. Ire Genre. Scinques. II Section. Lépidoglosses conopsides. Jer Groupe. Tiliguas, but neither Tiliqua lessonii nor Tiliqua kienerii are mentioned in the available part. Thus, for the moment there is no indication that these nomina were published by Cocteau under the requirements of the Code. Gabriel Bibron should have received the manuscript (Anonymous 1838a) but it is not available in the libraries of MNHN.

Tiliqua kienerii Cocteau - Duméril \& Bibron 1839: 654. Status. Poieonym; should figure in the synonymy list of Emoia cyanura (fide Duméril \& Bibron 1839: 656).

Onomatophore. Holophoront. Now lost.

Onymotope. Not indicated.

\section{COMMENT}

Based on a single faded specimen among the series of specimens from the Paris Museum collection (Duméril \& Bibron 1839: 656). The specimen was not mentioned by Duméril \& Duméril (1851) (see also Brygoo 1985). The best choice would be to designate as neophoront the neophoront of Scincus cyanurus to resolve ambiguity. For nomenclatural availability see Comment on the nomen above. As the nomen was published as synonym and not used as valid nomen before 1961, it is not available (Article 11.6).

Emoia pheonura Ineich, 1987: 491.

Status. Doxisonym (subjective synonym) of Scincus cyanurus Lesson, 1828 (Brown 1991: 64; Ineich \& Zug 1991: 1134).

Onomatophore. Holophoront by original designation MNHNRA-1987.1301.

Onymotope. French Polynesia, Society Islands, Moorea Island, Opunohu Bay $\left(17.495^{\circ} \mathrm{S}, 149.857^{\circ} \mathrm{W}\right)$, on the shore.

\section{CONCLUSION}

Although the accepted dates of the publications of the nomen Scincus cyanurus have changed in the recent years, the identity of the taxon is on the one hand relatively stable, on the other difficult to assess without molecular data, and can only be stabilised if the neophoront designation for Scincus cyanurus is done judiciously. Beside the publication date and onomatophore of this nomen, the status of the nomina Eumeces lessonii, Scincus celestinus, Tiliqua lessonii, Tiliqua kienerii and Emoia pheonura, listed in the synonymy of Scincus cyanurus, has been clarified. Study of specimens originally linked to the nomen allowed us to confirm that Scincus celestinus, a gymnonym, should be changed to the synonymy list of Emoia caeruleocauda.

Emoia species are interesting models for biogeographic studies showing distribution patterns both linked to natural and anthropogenic invasions of islands (Klein et al. 2016). The main difficulty is the large range and the poor morphological differentiation of the species linked to high intra-specific variation already observed by Duméril \& Bibron (1839). Molecular methods will be very useful to understand evolutionary history of these skinks, and are necessary to correctly chose a specimen as neophoront for one of the earliest described Emoia species, Scincus cyanurus.

\section{Acknowledgements}

We thank Aaron Bauer (Villanova University), Andrea Kourgli and Georg Gasser (NMW), Victoire Koyamba (MNHN) and Frank Tillack (ZMB) for providing access to their bibliographic resources. The manuscript has benefited from the comments of a colleague wishing to remain anonymous.

\section{REFERENCE}

ANONYmous [A. L.]. 1838a - Nécrologie. Revue zoologique 1838: 91-96.

ANONYMOUS. $1838 \mathrm{~b}$ - Nouvelles scientifiques. Annales françaises et étrangères d anatomie et de physiologie 2: 256-260.

ANONYMOUS [INTERNATIONAL COMMISSION ON ZOOLOGICAL NOMENClatURE]. 1999. - International code of zoological nomenclature. 'Fourth edition'. International Trust for zoological Nomenclature, London: i-xxix + 1-306.

Brown W. C. 1991. — Lizards of the genus Emoia (Scincidae) with observations on their evolution and biogeography. Memoirs of the California Academy of Sciences 15: i-vi + 1-94.

BRYGOO E. R. 1985. — Les types de Scincidés (Reptiles, Sauriens) du Muséum national d'Histoire naturelle. Catalogue critique. Bulletin du Muséum national d'Histoire naturelle (4) A7 (3 suppl.): 1-126. https://www.biodiversitylibrary.org/page/58710077

Buden D. W. \& Toboroši D. 2016.- Reptiles of the Federated States of Micronesia. Island Research \& Education Initiative, Palikir, Phonpei: 1-311.

Buden D. W., TAboroši D., Kottermair M., Jalandoni A. \& Martin M. 2020. — Reptiles of the Northern Marshall Islands. Pacific Science 74: 189-209. https://doi.org/10.2984/74.2.8

ChAmISO A. VON 1821. - Bemerkungen und Ansichten auf einer Entdeckungs-Reise unternommen in den Jahren 1815-1818. Band 3: 1-240.

COCteau J. T. 1836. - Études sur les Scincoïdes. Paris (Terzuolo imp.): $[\mathrm{i}-\mathrm{x}]+1-9+[\mathrm{i}-\mathrm{ii}]+1-8+1-8+[\mathrm{i}-\mathrm{ii}]+1-8+[\mathrm{i}-\mathrm{ii}], 4$ pl. (exemplars 
of Biodiversity Heritage Library from Harvard University Library and from Library of Reptiles \& Amphibien Lab in the MNHN, NMW, Library of Herpetology Section, ZMB, Zoologische Hauptbibliothek). Pagination of the second part, from a private library, to be considered unpublished: [i-ii] + 1-12+ [i-ii]. In Worldcat and all library catalogues in which we could find details for this book, only the first part is mentioned, with 4 plates. The second part was announced, probably printed, but never published as Cocteau passed away suddenly. Various sources from mid-19th century and library catalogues mention expressly that only part 1 was published. The unpublished pages of the Cocteau book are available as pdf from the authors. https://doi.org/10.5962/bhl.title.5013

CowAN C. F. 1970. - The Insects of the Coquille Voyage. Journal of the Society for the Bibliography of natural History 5 (5): 358-360. https://doi.org/10.3366/jsbnh.1970.5.5.358

Cretella M. 2010. - The complete collation and dating of the section Zoologie of the Coquille voyage. Bolletino Malacologico 46 (2): 83-103.

DE VIS C. W. 1892. — Zoology of British New Guinea. Part I.Vertebrata. Annals of the Queensland Museum 2: 3-12. https:// www.biodiversitylibrary.org/page/48070264

Dubois A. \& RAFFAËLLI J. 2009. - A new ergotaxonomy of the family Salamandridae Goldfuss, 1820 (Amphibia, Urodela). Alytes 26 (1-4): 1-85.

Duméril A. M. C. \& Bibron G. 1839. - Erpétologie générale ou Histoire naturelle complète des Reptiles. Tome 5. Librairie Encyclopédique de Roret, Paris: i-viii + 1-854, errata.

Duméril C. \& Duméril A. 1851. - Catalogue méthodique de la collection des Reptiles. Gide et Baudry, Paris: i-iv + 1-224. https://gallica.bnf.fr/ark:/12148/bpt6k883907t

Frétey T., DeWynter M. \& Ohler A. 2018. - Onymotopes in zoological nomenclature: some additional terms, with fixation of a lectonymotope for Xenopus petersii Bocage, 1895 (Amphibia, Anura). Bionomina 13: 37-50. https://doi.org/10.11646/bionomina.13.1.3

GARNOT P. 1825. - Relation d'un naufrage sur les côtes d'Afrique, au mois de juillet 1824. Annales maritimes et colonales 2: 335-351.

Guérin-Méneville F. C. 1838. — Première division. Crustacés, Arachnides et Insectes, in LESSON R.-P., Zoologie, in DUPERREY L. I., Voyage autour du monde, exécuté par Ordre du Roi, sur la corvette de Sa Majesté, La Coquille, pendant les années 1822, 1823 , 1824 et 1825. Arthus Bertrand, Paris, 2 (2): i-xii + 9-319. https:// www.biodiversitylibrary.org/page/ 12003895

GuiBÉ J. 1954. — Catalogue des types de Lézards du Muséum national d'Histoire naturelle. Imprimerie Colas, Bayeux: 1-119.

INEICH I. 1987. - Description d'une nouvelle espèce du genre Emoia (Sauria, Scincidae) en Polynésie française. Bulletin du Muséum national d'Histoire naturelle (4) A 9 (2): 491-494. https://www. biodiversitylibrary.org/page/58700327

InEICH I. 2011. - Amphibians and Reptiles, in BoucheT P., Le Guyader H. \& Pascal O. (ed.), The natural history of Santo. Muséum national d'Histoire naturelle, Institut de Recherche et de Développement \& Pro-Natura International, Paris, Marseille \& Paris, Patrimoines naturels 70: 187-236.

INEICH I. \& ZUG G. R. 1991. - Nomenclatural status of Emoia cyanura (Lacertilia, Scincidae) populations in the central Pacific. Copeia 1991 (4): 1132-1136. https://doi.org/10.2307/1446114

InEICH I., BEROT S. \& GARROUSTE R. 2009. — Les reptiles terrestres ou comment survivre en devenant "vampires", in CHARPY L. (ed.) Clipperton, environnement et biodiversité d'un microcosme océanique., MNHN \& IRD, Paris \& Marseille, Patrimoines naturels 68: 347-380.

KLeIN E., Harris R., Fisher R. \& ReEder T. 2016. — Biogeographic history and coalescent species delimitation of Pacific Island Lizards (Squamata: Scincidae: Emoia cyanura species group). Journal of Biogeography 43: 1917-1929. https://doi.org/10.1111/jbi.12772

LESCURE J. 2015. - René-Primevère Lesson (1794-1849), pharmacien de la marine, voyageur-naturaliste et herpétologiste. Bulletin de la Société herpétologique de France 155: 1-50.

LESSON R.-P. 1828. — Observations générales sur les Reptiles observés dans le voyage autour du monde de la corvette la Coquille. Annales des Sciences naturelles 13: 369-394.

LESSON R.-P. 1830a. - Histoire naturelle, Zoologie. Atlas, in DUPERREY, L. I., Voyage autour du monde, Exécuté par Ordre du Roi, sur la Corvette de Sa Majesté, La Coquille, pendant les années 1822, 1823, 1824 et 1825. Arthus Bertrand, Paris : Reptiles pl. 2 \& 4. https://doi.org/10.5962/bhl.title.57936

LESSON R.-P. 1830b. — Observations générales sur les Reptiles recueillis dans le voyage autour du monde de la corvette La Coquille, in LESSON R.-P., Zoologie, in DUPERREY L. I., Voyage autour du monde, Exécuté par Ordre du Roi, sur la Corvette de Sa Majesté, La Coquille, pendant les années 1822, 1823, 1824 et 1825. Arthus Bertrand, Paris 2 (1): 1-23. https://doi.org/10.5962/bhl.title.57936

LESSON R.-P. 1831. - Description des quelques Reptiles nouveaux ou peu connus, in DUPERREY L. I., Voyage autour du monde, Exécuté par Ordre du Roi, sur la Corvette de Sa Majesté, La Coquille, pendant les années 1822, 1823, 1824 et 1825. Arthus Bertrand, Paris 2 (1): 34-65. https://doi.org/10.5962/bhl.title.57936

LESSON R. P. 1838. - Appendix. Tableau indicatif des collections faites dans chaque relâche et remises au Muséum d'Histoire naturelle à Paris, in LESSON R.-P., Zoologie, in DUPERREY L. I., Voyage autour du monde, exécuté par ordre du roi, sur la corvette de Sa Majesté, La Coquille, pendant les années 1822, 1823, 1824 et 1825. Arthus Bertrand, Paris 2 (2): 137-147. https://doi. org/10.5962/bhl.title.57936

LESSON [R.-] P. 1838-1839. - Voyage autour du monde, entrepris par ordre du gouvernement sur la Corvette La Coquille, Pourrat frères, Paris 1: 1-510 + [i], 17 pl.; 2: 1-547 + [i-ii], 26 pl. [Parts $1 \& 2$ published before 7 april 1838 according to Bibliographie de la France 27 (14): 166.]

QuOY [J. R. C.] \& GAIMARD [J. P.] 1824. - Zoologie, in FreYCINET L. DE (ED.), Voyage autour du monde, entrepris par ordre du Roi, sous le Ministère et conformément aux instructions de S. Exc. le Vicomte du Bouchage, Secrétaire d'État au Département de la Marine, exécuté sur les corvettes de S. M. l'Uranie et la Physicienne, pendant les années 1817, 1818, 1819 et 1820... Pillet Aîné, Paris: [i-vii] + 1-712. https://doi.org/10.5962/ bhl.title.62491

SEBA A. 1735. - Locupletissimi rerum naturalium thesauri accurata descriptio, et iconibus artificiosissimis expressio, per universam physices historiam. Opus, cui, in hoc rerum genere, nullum par exstitit. Ex toto terrarum orbe collegit, digessit, descripsit, et depingendum curavit Albertus Seba, Etzela Oostfrisius, Academia Caesarea Leopoldino Caroline Nature Curiosorum Collega Xenocrates dictus; Societatis Regia Anglicane, et Instituti Bononiensis, sodalis. Tomus II. Amstelaedami (J. Wetstenium, G. Smith \& Janssonio-Waesbergios): [i-xxx] + 1-154, 114 pl. https://gallica.bnf.fr/ark:/12148/bpt6k15137356 SHerborn C. D. 1932. - Index Animalium sive Index nominum quae ab a.d. MDCCLVIII generibus et speciebus animalium imposa sunt. Sectio secunda a kalendis ianuariis, MDCCCI usque ad finem decembris, MDCCCL. London (British Museum): v-vi + cxxxiiicxlviii + 1-208.

Sherborn C. D. \& Woodward B. B. 1901. — Notes on the dates of publication of the natural history portions of some French Voyages. - Part I. 'Amérique méridionale'; 'Indes orientales'; 'Pôle Sud' ('Astrolabe' and 'Zélée'); 'La Bonite'; 'La Coquille'; and 'L'Uranie et Physicienne.' Annals and Magazine of Natural History (7) 7 (40): 388-392. https://www.biodiversitylibrary. org/page/26195931

Sherborn C. D. \& Woodward B. B. 1906. - Notes on the dates of publication of the natural history portions of some French Voyages. "Voyage autour du monde ... sur ... La Coquille pendant ... 1822-25 ... par L. I. Duperrey \&c. - A correction. Annals and Magazine of Natural History (7) 17 (99): 335-336.

Submitted on 21 September 2020; accepted on 16 Mars 2021; published on 5 October 2021 